\title{
Preparation and Characteristics of Cellulose Acetate Based Nanocomposites Reinforced with Cellulose Nanocrystals (CNCs) ${ }^{1}$ (KP:P
}

\author{
Jae-Gyoung Gwon ${ }^{2} \cdot$ Dan-Bee Lee ${ }^{2} \cdot$ Hye-Jung Cho $^{2} \cdot$ Sun-Young Lee $\mathbb{B}^{2, \dagger}$
}

\begin{abstract}
Cellulose acetate (CA) has been widely utilized for composite materials due to its high transparency and thermal resistance. In this study, CNCs (cellulose nanocrystals) were reinforced in CA nanocomposites for fortifying mechanical properties of the composites. In addition, CA nanocomposites reinforced with CNCs were manufactured by extrusion/ injection processes applied with CNC-predispersion method for achieving a high dispersion level of CNCs in the CA matrix. According to the analysis of mechanical properties, the CA nanocomposite with 3 wt\% CNCs has the highest tensile and flexural strengths due to the reinforcing effect of CNC nanoparticles. Thermogravimetric analysis (TGA) showed that the addition of acid hydrolyzed CNCs slightly lowered the initial pyrolysis temperature of CA nanocomposite.
\end{abstract}

Keywords: cellulose nanocrystals, cellulose acetate, predispersion, percolation effect, thermogravimetric analysis

\section{INTRODUCTION}

Recently, many scientists and industries have been interested in nanopolymer composites mixed with various nanoparticles because of the remarkable improvement of the matter properties. Although various petroleum-based polymer materials have been used to develop nanocomposites, the development of nanocomposites using biodegradable polymers derived from nature has attracted great interest due to the global warming and the various environmental regulations surrounding the disposal of polymers. Poly (3-hydroxybutyrate) (PHB), poly (lactic acid) (PLA), cellulose acetate (CA) and poly (caprolactone) (PCL) are popular biodegradable polymers replacing petroleumbased polyolefin polymers (Gutierrez et al., 2012).

Cellulose acetate, a cellulose derivative, as a representative biodegradable polymer, is synthesized through acetylation of cellulose and excessive acetic anhydride by sulfuric acid catalyst (Korea Textile Development Institute, 2012). CA is widely used for the development of composite materials such as expensive spectacle frames, high-grade fibers, and window frames because of its transparency, stiffness, heat and impact resistance. It is also widely used in water treatment fields such as reverse osmosis, ultrafiltration and nanofiltration because of its low price, good chlorine resistance, bio and water affinity.

1 Date Received August 17, 2018, Date Accepted September 8, 2018

2 National Forestry Research Institute, Forest Products Department, National Institute of Forest Science, Seoul 02455, Republic of Korea

† Corresponding author: Sun-Young Lee (e-mail: nararawood@korea.kr, ORCID: 0000-0002-9189-9095) 
In addition, due to the non-toxicity, biocompatibility and absorbability of CA, a natural material, it has recently been widely used in the study of medical engineering materials for drug delivery and hemodialysis (Candido et al., 2017; Dumitriu et al., 2018; Liu et al., 2016, Chun et al., 2012; Sukul et al., 2015). Despite these advantages, however, its low mechanical strength has been an impediment to the long-term use of CA in such applications.

Nanocellulose, which can be obtained through a mechanical or chemical treatment on plant cell walls, can be supplied from nature, and therefore, it is possible to continuously produce nanoparticles because of its sustainability. And since it has competitive price, it is being used for a variety of application fields requiring high-tech materials. Cellulose nanocrystals, a kind of nanocellulose, are nano-sized crystalline particles having a diameter of 5-70nm and a length of $100 \mathrm{~nm}$. CNC nanoparticles have a low density $\left(1.6 \mathrm{gcm}^{-3}\right)$ and a high specific surface area $\left(300 \mathrm{~m}^{2} \mathrm{~g}^{-1}\right)$ and shows high tensile strength (7.5-7.7 GPa) and elasticity (143 GPa) (Gwon et al. , 2018; Majoinen et al., 2011; Ljungberg et al., 2006; Moon et al., 2011). These features of CNCs are good enough for researchers to use as a reinforcing agent to increase the strength of polymer composite materials (Jo et al., 2015; Masruchin et al., 2015; Park et al., 2016). Moreover, the CNCs surface structure with many hydroxyl groups (-OH) similar to that of the CA main chains makes it possible to fabricate composites in a simple process, compared to the studies in which the surface of hydrophilic CNCs was modified to hydrophobicity (Gwon et al., 2016) for use as a reinforcing agent for hydrophobic polymer composites. Many hydrogen bonds between the two materials can be expected to serve as effective enhancers in the CA composite materials.

To date, the majority of CA application research has focused on the production of materials by electrospinning, using chemicals or organic solvents that have big environmental load such as dichloromethane and methanol. On the other hand, there are relatively few studies on the CA production using molten extrusion and injection methods which are advantageous for mass production for industrialization. Therefore, the aims of this study are to introduce the development of CA polymer composite materials using CNCs as a reinforcing agent by applying an extrusion and injection method and to investigate the mechanical and thermal properties of CA composite materials made according to the CNCs content.

\section{MATERIALS and METHODS}

\subsection{Testing materials}

Cellulose acetate (Mn 50,000 Da, Sigma-aldrich) is used as a base polymer and has 39.7 wt.\% of the acetyl group. (For improving flowability of CA during
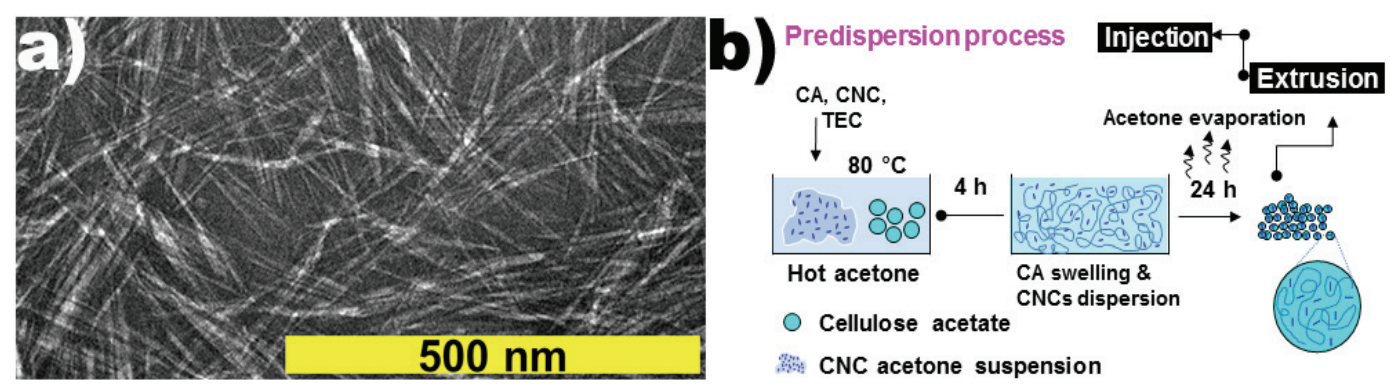

Fig. 1. a) TEM image for isolated CNCs and b) experimental scheme for predispersion. 
Preparation and Characteristics of Cellulose Acetate Based Nanocomposites Reinforced with Cellulose Nanocrystals (CNCs)

extrusion and injection processes, triethyl citrate (TEC, Mw 273.3 Da, Alfa Aesar) was used as an environmentally friendly plasticizer with low volatility at the processing temperature.) Cellulose nanocrystals were prepared according to the previous experimental method (Gwon et al., 2016) using 64\% of the sulfuric acid in a cellulose powder (W-50, KC Flock) with a particle size of $50 \mu \mathrm{m}$. The diameter of CNCs fabricated was about $6.0 \pm 1.2 \mathrm{~nm}$, and the length was $155 \pm 15 \mathrm{~nm}$ [Fig. 1(a)]. Before using the melting process, the CNC suspension solvent was refrigerated at $5{ }^{\circ} \mathrm{C}$ after replacing distilled water with acetone to disperse CNC nanoparticles in the CA resins in advance.

\subsection{Composite material fabrication}

To investigate the properties of CA nanocomposites based on the CNC's content, we divided the CNCs content into $0,1,3,5$, and 10 wt.\%. TEC, a plasticizer added to improve the efficiency of the melting process was set to $30 \mathrm{wt}$ \% of the total weight. To effectively disperse the CNC nanoparticles between the CA main chains, a predispersion method using solvents was applied to the process (Gwon et al., 2018). When nanocomposites are fabricated through the melting process, the viscosity of the polymer is high at the molten state of the polymer, and therefore, the nanoparticles do not sufficiently disperse in the matrix, and an aggregation occurs so that the function of the nanoparticles as a reinforcing agent is difficult to carry out. Hence, nanoparticles are made to be predispersed in a solvent, and when the solvent penetrates into the spaces among the chains by inducing the expansion of the polymer chains in the solvent, the nanoparticles are moved with the solvent to the space when removing the solvent used later. Therefore, introducing the predispersion method make the nanoparticles possible to highly dispersed state in the molten polymer matrix.

It is desirable that the conditions of the solvent used here satisfy both the affinity to the nanoparticles and the good solvent for the polymer resin. In this study, we used the predispersion method that uses acetone, and it's shown in Fig. 1b. The suspension of CNCs replaced with acetone was put into acetone which was about twice as heavy as the CA weight. Then, the mixture was stirred at $14,000 \mathrm{rpm}$ for 5 minutes using a high-speed homogenizer (Ultra Turrax T25, IKA). After that, temperature of the mixture was raised to $80^{\circ} \mathrm{C}$ by using a hot water bath. When the temperature rose, CA and TEC were added to completely dissolve $\mathrm{CA}$, and then the solvent was evaporated in the hood for 24 hours after casting it into the stainless-steel mold. After the evaporating process, the solvent was removed and then a CA/CNC composite film was formed in the mold. The size of this fabricated film was about $400 \times 400 \times 1 \mathrm{~mm}$ (width $\times$ length $\times$ thickness). The film $(5 \times 3 \mathrm{~mm})$ was pelletized by using a pelletizer (Bautek Co.) and then dried it in an $80^{\circ} \mathrm{C}$ oven for 24 hours before starting extrusion process. The pelletized films were extruded by a co-rotating twin-screw extruder (19 mm diameter, $40 \mathrm{~L} / \mathrm{D}$ ratio, Bautek Co.). The extrusion temperature and screw speed were $170 \sim 185^{\circ} \mathrm{C}$ and 150 rpm respectively. Extruded materials were immediately conveyed to an injection machine (Minijet II, Thermo Scientific) for preventing any strand formation.

\subsection{Evaluation of properties}

The mechanical (tensile and flexural) properties of the prepared CA/CNC nanocomposites were evaluated by using a universal testing machine (GB / H50K, Hounsfield test equipment Ltd.). The five specimens were tested according to the ASTM D638 and D790 methods and the test speed was $10 \mathrm{~mm} / \mathrm{min}$. The thermal properties of composites were obtained using TGA (Thermogravimetric Analyzer, Perkin-Elmer TGA8000) at a $10{ }^{\circ} \mathrm{C} / \mathrm{min}$ in the $40{ }^{\circ} \mathrm{C}$ to $600{ }^{\circ} \mathrm{C}$ temperature range under helium. 


\section{RESULTS and DISCUSSION}

\subsection{Mechanical properties of $\mathrm{CA} / \mathrm{CNC}$ nanocomposites}

Fig. 2 shows the tensile and flexural properties of $\mathrm{CA} / \mathrm{CNC}$ nanocomposites based on the CNCs content. The tensile strength of the composites showed a maximum value of about $36 \mathrm{MPa}$ when the content of CNCs was 3 wt.\%, which was a strength increase of about $24 \%$ compared to that of CA without CNCs. Tensile modulus tended to increase as the content of
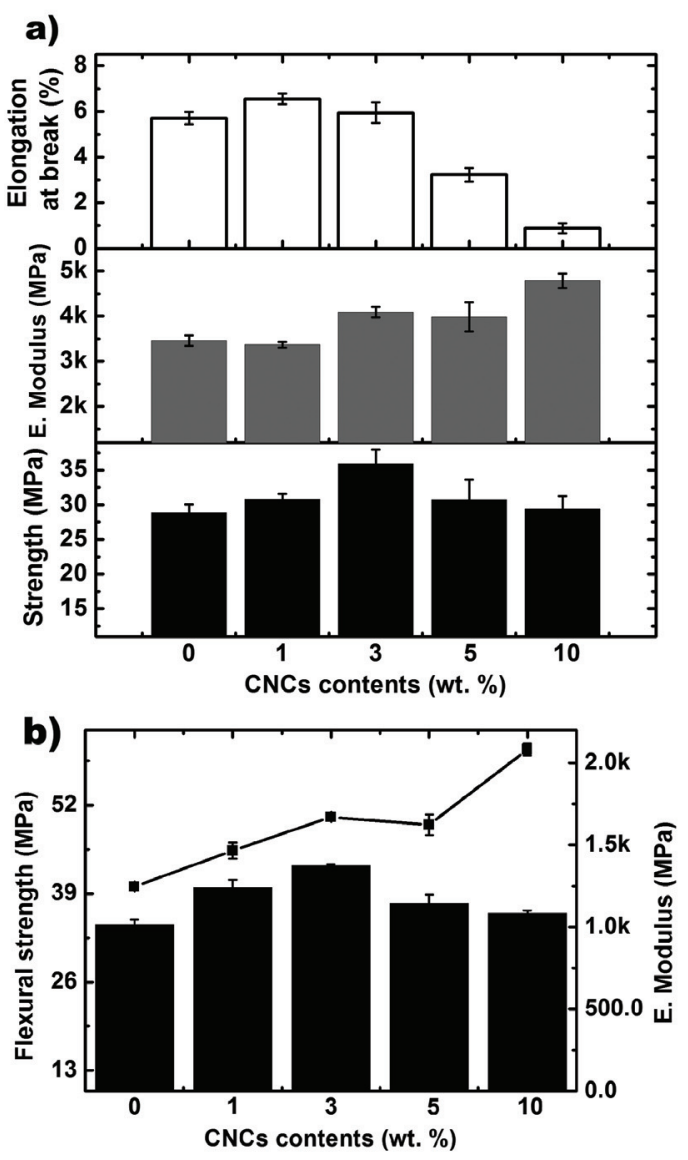

Fig. 2. a) Tensile properties and b) Flexural properties of CA/CNC nanocomposites as a function of CNCs contents.
CNCs increased, and the maximum elongation at break dramatically reduced when the content of CNCs was 3 wt.\%. Like the tensile strength, the flexural strength showed a maximum value of $43 \mathrm{MPa}$ when the content of CNCs was 3 wt.\% and a strength increase of $26 \%$ when compared to CA without CNCs. The flexural modulus also increased as the CNC nanoparticle content increased. The reason for the improvement in strength is due to the reinforcing effect of the CNC nanoparticles, and when the CNC is well dispersed in the CA resin, it prevents the CA resin from being broken by force from outside. The area that we need to take a closer look at is where the strength of $\mathrm{CNC}$ nanocomposites with CNCs shows a maximum value when the content of the CNC nanoparticles was 3 wt.\%. Afterwards, the strength tends to decrease as the content decreased. The reason for this decrease in strength is due to the flocculation phenomenon of CNC 'nanoparticles'. In other words, the external forces are focused on the place where the particles agglomerate without being evenly distributed. The cause of the reduction in strength due to the flocculation of rodshaped nanoparticles such as CNCs can be explained in detail by mechanical percolation (Leite et al., 2016; Dufresne 2008; Dong et al., 2012; Azizi et al., 2005). In the case of studies where percolation is an infinite connection in terms of mechanical properties, this phenomenon can be seen as a phenomenon in which percolation network formation of CNC nanoparticles occurs at the molecular level by a means of hydrogen bonding at a specific content or above. The content that starts this flocculation is the mechanical percolation threshold $\left(\nu_{\mathrm{Rc}}\right)$ which can be obtained from the following equation:

$$
\nu_{\mathrm{Rc}}=0.7 /(\mathrm{L} / \mathrm{D})
$$

In the case of CNCs used in this study with $\mathrm{L} / \mathrm{D}$ being the aspect ratio of the nanoparticles, $\mathrm{L} / \mathrm{D}$ was about 26, and $\nu_{\mathrm{Rc}}$ was 2.6 vol.\%. Considering that 
the density of CNCs is $1.5 \mathrm{gcm}^{-3}$ (Leite et al., 2016), flocculation of CNCs occurs at about 4.0 wt.\%, which is one of the reasons why the reduction in strength occurs. The modulus is the stiffness of the material, and even though the CNCs agglomerate due to the strong CNC particles, external stress can be transferred to both the resin and the particles. Therefore, the stiffness of the composite material itself may increase as the content of the nanoparticles increases. The enlogation at break is the capability of a resin to exhibit viscoelasticity, but in this study, the CNCs were simply used as a filler, so that the enlogation at break of the resin itself could not be improved. When a filler is added, the maximum elongation at break can be reduced because the resin endures greater force and breaks without any deformation. After the nanoparticle flocculation occurs, the maximum load value becomes smaller and a flocculation phenomenon occurs. Therefore, the value is lowered because the composite material may be broken with less force.

\subsection{Thermal properties of $\mathrm{CA} / \mathrm{CNC}$ nanocomposites}

Fig. 3 shows the thermal behavior of CA/CNC composites by TGA (thermogravimetric analysis). The weight reduction rate of the composite materials by the thermogravimetric analysis is shown in Fig. 3a, and the derivative value thereof is shown in $3 \mathrm{~b}$. The pyrolysis of CA/CNC composites with plasticizer has been reported to occur mainly in three stages (Leite et al., 2016). The first stage is caused by the evaporation of residual water remaining in the composite material at $130-240{ }^{\circ} \mathrm{C}$. The second stage occurs in a temperature range of $250-330{ }^{\circ} \mathrm{C}$ where the acetyl group decomposes from the main chains of CA while forming acetic acid. The decomposition of TEC plasticizers occurs extensively in the temperature ranges of the first and second stages. The last stage, or the third stage, occurs at 350 to 425 ${ }^{\circ} \mathrm{C}$ due to thermal degradation of the main chains of CA (Claro et al., 2016; Leite et al., 2016).
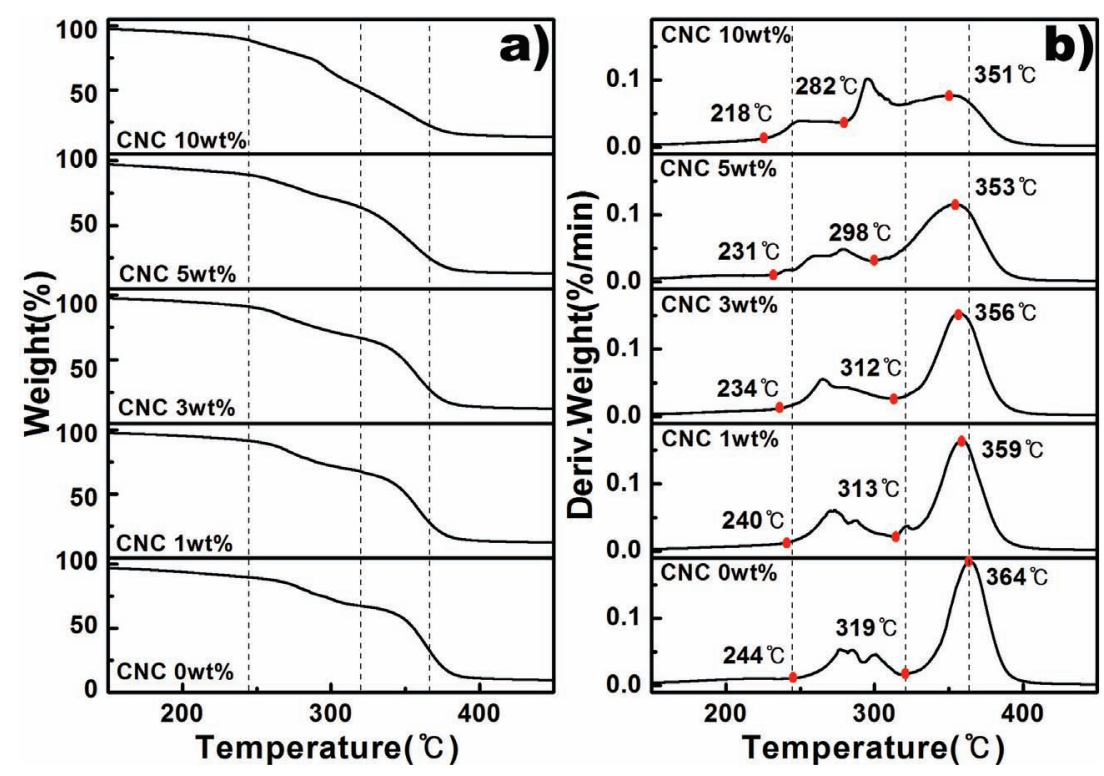

Fig. 3. TGA results of CA/CNCs nanocomposites: a) weight loss, and b) derivative weight as a function of temperature. 
In this study, thermal behavior caused by residual moisture in the composite materials was not seen, because the pressure and injection process using high temperature $\left(>160{ }^{\circ} \mathrm{C}\right)$ was used when the composite materials were being fabricated. As shown in Fig. 3b, the CA/CNC composite materials are thermally degraded in two stages, having a main peak between about $200-320{ }^{\circ} \mathrm{C}$ and $320-400{ }^{\circ} \mathrm{C}$. Therefore, it is thought that the acetyl groups in the main chains of TEC and CA, which are plasticizers, are decomposed in the first pyrolysis zone, and the main chain of CA is decomposed in the second thermal degradation zone. There are two points to be noted in the differential graph of the weight reduction rate (Fig. 3b). The first is the decomposition behavior of sulfuric acid-treated CNCs. CNCs produced by sulfuric acid hydrolysis is mainly pyrolyzed at over 170 to $250{ }^{\circ} \mathrm{C}$ (Gwon et al., 2016). Unsulfurized CNCs begin decomposition at 330 ${ }^{\circ} \mathrm{C}$ (Leite et al., 2016). However, CNCs produced by sulfuric acid hydrolysis start to decompose at about $170-180{ }^{\circ} \mathrm{C}$ due to the catalyzed thermal degradation teaction of sulfate functional groups on CNCs surface. However, in this study, the decomposition behavior of the composite materials with CNCs added at the above temperature was not observed. The reason is that the thermal stability of the CNC is improved between the CNCs surface and the CA main chains by strong hydrogen bonding. The second point to be note is that the onset temperature of the above two zones decreases as the CNCs content increases. As described above, plasticizer was added to the first thermal degradation zone, and CNCs were added to the acetyl group decomposition zone of CA. CNCs themselves increase their decomposition temperature through interaction with CA. However, it seems that the temperature that starts thermal degradation in this zone rose because CNCs themselves act as an acid catalyst promoting pyrolysis due to the sulfate group attached to the surface. As the CNCs content increases, the thermal decomposition of the CA main chains of the second zone is sped up because CNCs generate large amount of decomposition gas during thermal degradation, and these gases form a lot of voids in the polymer resins and induce decomposition of the polymers to cause a change in the thermal diffusion mechanism (Leite et al., 2016). Consequently, the addition of sulfuric acid-treated CNC nanoparticles does not improve the thermal stability of the polymer composites because of the sulfate groups formed on the surface by sulfuric acid. However, since CNCs are a highly compatible chemical with CA, CNCs' surface can be chemically modified or overcome this issue by introducing a flame retardant.

\section{CONCLUSION}

This study analyzed how the addition of CNCs using the predispersion and the extrusion and injection methods affects the fabrication and properties of CA nanocomposites. In fabricating CA composites, the predispersion method has improved the dispersibility of CNCs in the material, which leads to the reinforcing effect that improves the strength of the composite material. However, when the content of CNCs was more than 3 wt.\%, flocculation associated with the percolation effect of CNCs occurred, resulting in a decrease in strength. It was confirmed that the addition of CNCs did not improve the thermal stability while reducing the pyrolysis temperature of CA nanocomposites slightly. However, it can be overcome by surface modification of CNCs and injection of flammable materials. Therefore, CA nanocomposites with CNCs fabricated by the predispersion method and the pressure/injection method can be used in many industrial fields, and it is a manufacturing method capable of improving low mechanical strength, which has been a disadvantage of CA composite materials, and enabling mass production. 


\section{REFERENCES}

Lee, P.W., Eom, Y.G., Chung, Y.J. 1988. The distribution and type of crystals in woods of Ginkgo Max. Journal of the Korean Wood Science and Technology 16(3): 1-4.

Azizi Samir, M. A. S., Alloin, F., Dufresne, A. 2005. Review of recent research into cellulosic whiskers, their properties and their application in nanocomposite field. Biomacromolecules 6(2): 612-626.

Candido, R. G., Godoy, G. G., Goncalves, A. R. 2017. Characterization and application of cellulose acetate synthesized from sugarcane bagasse. Carbohydrate polymers 167: 280-289.

Chun, S. J., Choi, E. S., Lee, E. H., Kim, J. H., Lee, S. Y., Lee, S. Y. 2012. Eco-friendly cellulose nanofiber paper-derived separator membranes featuring tunable nanoporous network channels for lithium-ion batteries. Journal of Materials Chemistry 22(32): 16618-16626.

Claro, P. I. C., Neto, A. R. S., Bibbo, A. C. C., Mattoso, L. H. C., Bastos, M. S. R.,, Marconcini, J. M. 2016. Biodegradable blends with potential use in packaging: a comparison of PLA/chitosan and PLA/cellulose acetate films. Journal of Polymers and the Environment 24(4): 363-371.

Dong, H., Strawhecker, K. E., Snyder, J. F., Orlicki, J. A., Reiner, R. S., Rudie, A. W. 2012. Cellulose nanocrystals as a reinforcing material for electrospun poly (methyl methacrylate) fibers: Formation, properties and nanomechanical characterization. Carbohydrate Polymers 87(4): 2488-2495.

Dufresne, A. 2008. Polysaccharide nano crystal reinforced nanocomposites. Canadian Journal of Chemistry 86(6): 484-494.

Dumitriu, C., Voicu, S. I., Muhulet, A., Nechifor, G., Popescu, S., Ungureanu, C., ... Pirvu, C. 2018.
Production and characterization of cellulose acetate/titanium dioxide nanotubes membrane fraxiparinized through polydopamine for clinical applications. Carbohydrate polymers 181: 215-223.

Gutierrez, M. C., De Paoli, M. A., Felisberti, M. I. 2012. Biocomposites based on cellulose acetate and short curaua fibers: Effect of plasticizers and chemical treatments of the fibers. Composites Part A: Applied Science and Manufacturing 43(8): 1338-1346.

Gwon, J. G., Cho, H. J., Lee, D., Choi, D. H., Lee, S., Wu, Q., Lee, S. Y. 2018. Physicochemical and mechanical properties of polypropylene-cellulose nanocrystal nanocomposites: Effects of manufacturing process and chemical grafting. BioResources 13(1): 1619-1636.

Gwon, J. G., Cho, H. J., Chun, S. J., Lee, S., Wu, Q., Li, M. C., Lee, S. Y. 2016. Mechanical and thermal properties of toluene diisocyanate-modified cellulose nanocrystal nanocomposites using semi-crystalline poly (lactic acid) as a base matrix. RSC Advances 6(77): 73879-73886.

Gwon, J. G., Cho, H. J., Chun, S. J., Lee, S., Wu, Q., Lee, S. Y. 2016. Physiochemical, optical and mechanical properties of poly (lactic acid) nanocomposites filled with toluene diisocyanate grafted cellulose nanocrystals. RSC Advances 6(12): 9438-9445.

Jo, Y. J., Cho, H. J., Chun, S. J., Lee, S. Y. 2015. Mechanical and thermal properties of hydroxypropyl cellulose/TEMPO-Oxidized cellulose nanofibril composite films. Journal of Korean Wood Science Technology 43(6): 740-745.

Korea Textile Development Instute, Textile information team. 2012. Development trend of thermoplastic cellulose fibers

Kurokawa, N., Kimura, S., Hotta, A. 2018. Mechanical properties of poly (butylene succinate) composites with aligned cellulose-acetate nanofibers. Journal 
of Applied Polymer Science 135(24): 45429.

Leite, L. S. F., Battirola, L. C., da Silva, L. C. E., Goncalves, M. D. C. 2016. Morphological investigation of cellulose acetate/cellulose nanocrystal composites obtained by melt extrusion. Journal of Applied Polymer Science 133(44).

Liu, C., Li, X., Liu, T., Liu, Z., Li, N., Zhang, Y., ... Feng, X. 2016. Microporous CA/PVDF membranes based on electrospun nanofibers with controlled crosslinking induced by solvent vapor. Journal of Membrane Science 512: 1-12.

Ljungberg, N., Cavaille, J. Y., Heux, L. 2006. Nanocomposites of isotactic polypropylene reinforced with rod-like cellulose whiskers. Polymer 47(18): 6285-6292.

Majoinen, J., Walther, A., McKee, J. R., Kontturi, E., Aseyev, V., Malho, J. M., Ikkala, O. 2011. Polyelectrolyte brushes grafted from cellulose nanocrystals using Cu-mediated surface-initiated controlled radical polymerization. Biomacromolecules 12(8): 2997-3006.

Masruchin, N., \& Park, B. D., 2015. Manipulation of Surface Carboxyl Content on TEMPO-Oxidized Cellulose Fibrils. Journal of Korean Wood Science Technology 43(5): 613-627.

Moon, R. J., Martini, A., Nairn, J., Simonsen, J., Youngblood, J. 2011. Cellulose nanomaterials review: structure, properties and nanocomposites. Chemical Society Reviews 40(7): 3941-3994.

Park, C. W., Han, S. Y., Lee, S. H., 2016. Size fractionation of cellulose nanofibers by settling method and their morphology. Journal of Korean Wood Science Technology 44(3): 398-405.

Sukul, M., Min, Y. K., Lee, S. Y., Lee, B. T. 2015. Osteogenic potential of simvastatin loaded gelatin-nanofibrillar cellulose- $\beta$ tricalcium phosphate hydrogel scaffold in critical-sized rat calvarial defect. European Polymer Journal 73: 308-323. 


\title{
APPENDIX
}

\author{
(Korean Version)
}

\section{셀룰로오스 나노크리스탈 강화 셀룰로오스 아세테이트 나노복합소재 제조 및 특성}

요약 : 셀룰로오스 아세테이트(cellulose acetate, CA)는 높은 투명도와 열 저항성을 갖고 있어 복합소재 개발에 많이 응용되고 있다. 본 연구에서는 CA 복합재의 기계적 강도 개선을 위해 셀룰로오스 나노크리스탈 (cellulose nanocrystals, CNCs)을 강화제 로 첨가하였다. CA 수지 내부에 CNCs의 고른 분산을 위해 선 분산(predispersion)법 적용 후, 압출 및 사출하는 제조 방식으로 $\mathrm{CA}$ 복합재를 제조하였다. 기계적 특성 분석 결과, $\mathrm{CNCs}$ 를 $3 \mathrm{wt} \%$ 첨가하였을 때 강화효과(reinforcing effect)로 인해 최대 인장강도와 굴곡강도 값을 보임을 확인하였다. 열중량 분석법을 이용한 열분해 거동 분석을 통해 황산 처리된 CNCs의 첨가는 $\mathrm{CA}$ 복합소재의 열안정성을 약간 감소시키는 결과를 얻었다.

\section{1. 서 론}

최근 비약적인 물성 향상 때문에 많은 과학자와 산업체로부터 다양한 나노입자를 혼합한 나노고분자복합소재가 관심을 받고 있다. 그동안 다양한 석유기반의 고분자 소재가 나노복합소재 개발에 사용되었지만, 고분자의 폐기문제 발생에 의한 지구 온난화 및 각종 환경 규제 때문에 자연유래의 생분해성 고분자를 이용한 나노복합소재 개발이 큰 관심을 끌고 있다. Poly(3-hydroxybutyrate)(PHB), poly(lactic acid)(PLA), cellulose acetate(CA), poly(caprolactone)(PCL) 등이 그동안 석유기반 의 폴리올레핀 계열의 고분자를 대체하는 생분해성 고분자로 각광받고 있다(Gutierrez et al., 2012).

셀룰로오스 유도체인 셀룰로오스 아세테이트는 대표적인 생분해성 고분자로 황산 촉매 하에 셀룰로오스와 과량의 무수초산 의 아세틸화 반응을 통해 합성되어진다(한국섬유개발연구원, 2012). CA는 투명도, 강성, 열 및 충격 저항성에 이점을 가지고 있어 고가의 안경테, 고급섬유, 창호 등과 같이 복합소재 개발에 많이 응용되고 있으며, 낮은 가격, 적절한 염소 저항성, 바이오 및 수분 친화성 등의 특징으로 역삼투, 한외여과, 나노 분리막과 같은 수처리 분야에 많이 활용되고 있다. 또한, 천연 소재인 $\mathrm{CA}$ 가 가지는 무독성, 생체 친화성 및 흡수성은 최근 들어 약물전달 및 혈액투석과 같은 의공학 소재연구에도 많이 활용되고 있다(Candido et al., 2017; Dumitriu et al., 2018; Liu et al., 2016, Chun et al. 2012; Sukul et al. 2015). 그러나 이러한 장점에도 불구하고 낮은 기계적 강도가 상기 응용 분야에서 $\mathrm{CA}$ 의 장기적 사용의 저해 요인으로 고려된다.

식물 세포벽에 기계적 또는 화학적 처리를 통해 얻을 수 있는 나노셀룰로오스는 자연으로부터 원료를 공급받을 수 있기 때문에 원료수급 측면에서 지속적으로 나노입자를 생산할 수 있고, 가격 경쟁력을 갖추고 있기 때문에 다양한 첨단 소재 응용분 야에 적용되고 있다. 나노셀룰로오스의 한 종류인 셀룰로오스 나노크리스탈은 직경 5-70nm, 길이 $100 \mathrm{~nm}$-수 마이크로 크기의 결정형 나노셀룰로오스이다. CNC 나노입자는 낮은 밀도 $\left(1.6 \mathrm{gcm}^{-3}\right)$, 높은 비표면적 $\left(300 \mathrm{~m}^{2} \mathrm{~g}^{-1}\right)$ 을 가지고 있을 뿐 아니라 높은 인장강도(7.5-7.7 GPa)와 탄성(143 GPa)을 보인다(Gwon et al., 2018; Majoinen et al., 2011; Ljungberg et al., 2006; Moon et al., 2011). 이러한 CNCs의 특징은 연구자들로 하여금 고분자 복합소재의 강도 향상을 위한 강화제(reinforcement)로써 사용하기에 충분한 매력을 가지고 있다(Jo et al., 2015; Masruchin et al., 2015; Park et al., 2016). 특히 CA 사슬 주쇄의 구조와 유사한 많은 hydroxyl group(-OH)을 가지는 CNCs 표면 구조는 그동안 소수성 고분자 복합소재의 강화제로 사용하기 위해 친수성인 CNCs의 표면을 소수성으로 개질했던 연구(Gwon et al., 2016)에 비해 간단한 공정으로 복합소재를 제조 할 수 있으며, 이 둘 재료 사이의 많은 수소결합으로 CA 복합소재 내에서 효과적인 강화제 역할을 기대할 수 있다.

현재까지 대다수의 CA 응용 연구는 dichloromethane과 methanol 같은 환경부하가 큰 약제나 유기용매를 이용하여 전기방사 (electro-spinning)하는 방식으로 소재제조에 초점이 맞춰있다. 이에 비해 산업화를 위한 대량생산에 유리한, 용융방식의 압출 및 사출방식이 적용된 CA 제조에 관한 연구는 상대적으로 적다. 따라서 본 연구의 목적은 압·사출방식을 적용하여 CNCs를 강화제로 사용한 CA 고분자 복합소재 개발을 소개하고, CNCs 함량에 따라 제조된 CA 복합소재의 기계적 및 열적 특성을 조사하는데 있다. 


\section{2. 재료 및 방법}

\section{1. 공시재료}

셀룰로오스 아세테이트 (Mn 50,000Da, Sigma-aldrich)가 복합소재의 기반 사용되었으며, 39.7 wt.\%의 acetyl group을 가지고 있다. 압출 및 사출방식의 CA 용응공정에서 CA의 흐름성을 향상 시키고, 공정온도에서 휘산성이 적은 친환경 가소제로 써 트리에틸 시트레이트(triethyl citrate(TEC), Mw 276.3Da, Alfa Aesar)가 사용되었다. 셀룰로오스 나노크리스탈은 50um 입도를 가진 셀룰로오스 파우더(W-50, KC Flock)를 64\% 황산을 이용하여 이전 실험법(Gwon et al., 2016)에 따라 제조하였다. 제조된 CNCs는 직경 약 $6.0 \pm 1.2 \mathrm{~nm}$, 길이 $155 \pm 15 \mathrm{~nm}$ 였으며[Fig. 1a], 용융공정 도입 전 CA 수지내부에 CNC 나노입자를 선분산 시키기 위해 $\mathrm{CNC}$ 현탁액 용매를 증류수에서 아세톤(acetone)으로 치환하여 $5{ }^{\circ} \mathrm{C}$ 냉장보관 하였다.

\section{2. 복합소재 제조}

CNCs 함량에 따른 CA 나노복합소재의 특성을 살펴보기 위해 CNCs 함량은 $0,1,3,5,10$ wt.\%를 선정하였으며, 용융 공정효율 향상을 위해 투입된 가소제인 TEC는 전체 중량에 $30 \mathrm{wt} . \%$ 로 고정하였다. 효과적으로 CNC 나노입자를 CA 주쇄 사이에 분산을 위해 용매를 이용한 선분산법(predispersion method)을 이용하였다(Gwon et al., 2018). 용융을 통한 나노복합소 재 제조 시 단순히 고분자의 용융상태에서는 고분자의 점도가 높기 때문에 나노입자가 충분히 분산되지 않고 뭉침현상이 발생하므로 강화제로써 나노입자의 기능이 충분히 발휘되기 어렵다. 따라서 나노입자를 용매에 선분산 시키고 해당용매에 고분자 사슬의 팽창을 유도하여 용매가 사슬과 사슬사이에 침투될 때 나노입자를 함께 이동시켜 추후 사용된 용매를 제거하고 사슬사이에 나노입자만 남게 되어 고분자 수지 내에 나노입자가 고분산된 상태로 만드는 방법이다.

여기서 사용되는 용매의 조건은 나노입자의 친화성과 고분자 수지의 양용매(good solvent)를 모두 만족하는 것이 바람직하다. 본 연구에서는 아세톤을 이용한 선분산법을 적용하였으며 Fig. 1b에 나타내었다. 아세톤으로 치환된 CNCs 현탁액을 CA 중량에 2 배정도 되는 양의 아세톤에 투입 후, 고속 호모지나이져(Ultra Turrax T25, IKA)를 이용하여 14,000 rpm에서 5분간 교반 한다. 그 후 중탕기를 이용하여 $80^{\circ} \mathrm{C}$ 까지 온도를 상승시키고, 온도가 상승하면 $\mathrm{CA}$ 와 $\mathrm{TEC}$ 를 투입하여 완전히 $\mathrm{CA}$ 를 용해시킨 다음, stainless steel 몰드에 캐스팅 후 24h 동안 후드에서 용매를 증발 시킨다. 용매가 제거된 CA/CNC 복합필름을 몰드로부터 제거하였으며, 제조된 필름의 크기는 약 400×400×1 mm(가로×세로×두께)였다. 펠렛 제조기(pelletizer, Bautek Co.)를 이용하여 필름을 펠렛화 $(5 \times 3 \mathrm{~mm})$ 한 다음 용융 공정 도입 전 $80^{\circ} \mathrm{C}$ 오븐에서 $24 \mathrm{~h}$ 동안 건조시킨다. CA/CNC 복합펠렛을 이용하여 복합소 재 평가 시편을 제조하기 위해서 동회전 이축-스크류 압출기 (corotating twin-screw extruder, $19 \mathrm{~mm}$ diameter, $40 \mathrm{~L} / \mathrm{D}$ ratio, Bautek Co.)이 사용되었으며, 압출시 배럴온도는 $170 ~ 185{ }^{\circ} \mathrm{C}$, 스크류 속도는 약 $150 \mathrm{rpm}$ 였다. 압출기로부터 압출된 용융액은 strand 형성이나 펠렛 제조 없이 사출기(injection moder, Minijet II, Thermo Scientific)로 즉시 이송하여 시편을 제작하였다.

\section{3. 특성평가}

제조된 CA/CNCs 나노고분자복합소재의 기계적 특성평가는 만능시험기(GB/H50K, Hounsfield test equipment Ltd.)를 통해 이루어졌다. 인장 및 굴곡특성은 5개의 동일시편을 ASTM D638 및 D790 방법에 따라 진행하고 평균을 내었으며, 시험 속도는 $10 \mathrm{~mm} / \mathrm{min}$ 이었다. 열분해 특성 분석을 위하여 TGA(Thermogravimetric Analyzer, Perkin-Elmer TGA8000)를 이용하였다. 시료의 분석은 헬륨가스를 주입하면서 $10^{\circ} \mathrm{C} / \mathrm{min}$ 승온속도로 $40^{\circ} \mathrm{C}$ 에서 $600^{\circ} \mathrm{C}$ 의 온도범위에서 진행되었다,

\section{3. 결과 및 고찰}

\section{1. $\mathrm{CA} / \mathrm{CNCs}$ 나노고분자복합소재의 기계적 특성}

CNCs 함량에 따른 CA/CNCs 나노고분자복합소재의 인장 및 굴곡 특성을 Fig. 2에 나타내었다. 복합소재의 인장강도(tensile strength)는 $3 \mathrm{wt. \%} \mathrm{CNCs}$ 함량에서 약 $36 \mathrm{MPa}$ 으로 최대값을 보였으며, CNCs가 첨가되지 않은 CA에 비해 약 $24 \%$ 강도 상승을 보였다. 인장탄성률(tensile modulus)의 경우 CNCs 함량이 증가할수록 증가하는 경향을 보였으며, 최대연신율(elongation at break)의 경우 CNCs 함량이 $3 \mathrm{wt} . \%$ 에서 급격히 감소하는 것을 확인할 수 있다. 굴곡강도도 인장강도와 마찬가지로 $3 \mathrm{wt} \%$ $\mathrm{CNCs}$ 함량에서 약 $43 \mathrm{MPa}$ 으로 최대값을 보였으며, CNCs가 첨가되지 않은 CA에 비해 약 $26 \%$ 강도 상승을 보였다. 굴곡탄성률 (flexural modulus)도 CNC 나노입자의 함량 증가와 함께 상승하였다. 강도향상의 이유는 CNC 나노입자의 강화효과로 볼 수 있으며, CNC가 CA 수지 내부에 잘 분산되어 있을 경우 외부에 힘에 의해 CA 수지가 파단되는 것을 억제하기 때문이다. 여기서 
눈여겨 볼 구간은 $\mathrm{CNCs}$ 가 첨가된 $\mathrm{CA}$ 나노 복합소재의 강도가 $\mathrm{CNC}$ 나노입자의 함량이 $3 \mathrm{wt} . \%$ 에서 최대값을 보이고 그 이후 함량에서는 강도가 감소하는 경향을 보인다는 것이다. 이러한 강도 저하의 원인은 CNC'나노입자’의 뭉침(flocculation) 현상 때문으로 외부응력(stress)가 가해 졌을 때 작용되는 힘이 고르게 분산되지 못하고 입자가 뭉쳐진 곳으로 집중되기 때문이다. $\mathrm{CNCs}$ 와 같이 막대 형태의 나노입자의 뭉침 현상에 의한 강도 저하의 원인은 기계적 퍼컬레이션(mechanical percolation) 효과로 자세히 설명될 수 있다(Leite et al., 2016; Dufresne 2008; Dong et al. 2012; Azizi et al., 2005). 기계적 특성에서 퍼컬레이션은 무한한 연결이라는 개념으로 본 연구의 경우 CNC 나노입자들이 특정 함량 이상에서 수소결합(hydrogen bonding)에 의해 분자수 준에서 넓은 범위에서 연결(percolation network formation)이 발생되는 현상으로 이해할 수 있다. 이 뭉침 현상이 시작되는 함량은 기계적 퍼컬레이션 문턱 값으로 ( $v_{\mathrm{Rc}}$, mechanical percolation threshold) 아래의 식으로부터 구할 수 있다:

여기서 $\mathrm{L} / \mathrm{D}$ 는 나노입자의 종횡비로 본 연구에서 사용되는 $\mathrm{CNCs}$ 의 경우 약 26이고 $\mathrm{V}_{\mathrm{Rc}}$ 은 $2.6 \mathrm{vol} . \%$ 였다. CNCs의 밀도가 $1.5 \mathrm{gcm}^{-3}$ (Leite et al., 2016)인 것을 고려하면 약 $4.0 \mathrm{wt}$ \%에서 CNCs의 뭉침현상이 발생된다고 볼 수 있으며, 본 연구의 강도 저하의 원인을 뒷받침하는 근거가 된다. 계수(modulus)는 재료의 강성을 의미하는 것으로 CNCs의 뭉침현상이 발생함에도 불구하고 단단한 CNC 입자 덕택으로 외부응력을 수지와 입자 모두로 전달 할 수 있기 때문에 복합소재 자체의 강성은 나노입자 의 함량이 증가할수록 증가할 수 있다. 연신력의 경우 점탄성 특성을 보이는 수지가 늘어나는 능력이며, 본 연구에서는 CNCs가 단순히 충진제로 쓰였기 때문에 수지 자체의 연신력을 향상시킬 수 없다. 충진제가 첨가되었을 때 수지의 변형 없이 더 큰 힘을 더 견디고 파단되므로 최대연신율은 작아질 수 있으며, 나노입자의 뭉침현상이 발생된 이후에는 최대 하중값도 작아지고 뭉침현상이 발생이 되므로 적은 힘으로 복합소재의 파단이 발생될 수 있기 때문에 오히려 그 값은 떨어지게 된다.

\section{2. $\mathrm{CA} / \mathrm{CNCs}$ 나노고분자복합소재의 열분해 특성}

Fig. 3에 열중량 분석(TGA)에 의한 CA/CNC 복합소재의 열분해 거동을 나타내었다. 열중량 분석에 의한 복합소재의 중량 감소율을 Fig. 3a에 나타내었으며, 이의 미분값을 $3 \mathrm{~b}$ 에 나타내었다. 가소제(plasticizer)가 첨가된 CA/CNC 복합소재의 경우 열분해는 주로 3 단계에 걸쳐 발생된다고 보고되고 있다(Leite et al., 2016). 첫 단계는 $130-240^{\circ} \mathrm{C}$ 에서 복합소재에 남아 있는 잔여 수분의 증발에 의해 발생되며, 두 번째 단계는 CA의 주쇄로부터 아세틸기가 아세트산을 형성하면서 분해되는 $250-330^{\circ} \mathrm{C}$ 의 온도 범위에서 발생되며 첫 단계와 두 번째 온도 범위에서 TEC 가소제의 분해가 광범위하게 일어난다. 마지막 3단계는 CA의 주 사슬의 열분해로 $350 \sim 425^{\circ} \mathrm{C}$ 에서 발생된다(Claro et al., 2016; Leite et al., 2016).

본 연구에서는 복합소재 내에 잔여 수분에 의한 열분해 거동은 보이지 않으며, 이는 복합소재 제조 시 고온 $\left(>160^{\circ} \mathrm{C}\right)$ 을 사용하는 압-사출 공정이 적용되었기 때문이다. Fig. 3b에서 볼 수 있듯이, $\mathrm{CA} / \mathrm{CNCs}$ 복합소재는 약 $200-320^{\circ} \mathrm{C}$ 과 $320-400^{\circ} \mathrm{C}$ 사이에서 주 피크를 가지는 2 단계 걸쳐 열분해가 진행되는 것을 확인할 수 있다. 따라서 첫 번째 열분해 구간에서 가소제인 TEC와 CA의 주쇄에 있는 아세틸 그룹이 분해가 발생된다고 판단되며, 두 번째 열분해 구간에서 CA의 주 사슬의 분해가 발생된다고 볼 수 있다. 중량 감소율의 미분 그래프(Fig. 3b)에서 눈여겨 볼 점은 두 가지로 첫 번째의 황산 처리된 CNCs의 분해 거동이다. 황산 가수분해에 의해 제조된 CNCs의 자체의 경우, 주로 $170 ~ 250^{\circ} \mathrm{C}$ 에 걸쳐서 열분해가 발생된다(Gwon et al., 2016). 황산이 처리되지 않은 CNCs의 경우 $330^{\circ} \mathrm{C}$ 에서 분해가 시작되나(Leite et al., 2016) 황산 가수분해에 의해 생산된 CNCs의 경우, CNCs 표면의 sulfate 작용기의 열분해 반응의 촉매작용으로 인해 약 $170-180^{\circ} \mathrm{C}$ 근처에서 분해가 시작된다. 그러나 본 연구에서 CNCs 첨가된 $\mathrm{CA}$ 의 복합소재의 경우 상기 온도에서 분해거동이 보이지 않으며, 이는 $\mathrm{CNCs}$ 표면과 CA 주 사슬 사이의 강한 수소 결합에 의해 $\mathrm{CNC}$ 의 열안정성이 향상된 것으로 판단된다. 두 번째 주목할 점은 상기 두 구간의 분해 시작온도(onset temperature)가 CNCs 함량이 증가할수록 낮아진다는 점이다. 앞서 설명한 것처럼 첫 번째 열분해 구간은 가소제, CA의 아세틸 그룹의 분해 구간으로 CNCs가 첨가되면서 CNCs 자체는 CA와의 상호작용으로 분해온 도가 상승하나 표면에 붙어있는 sulfate기로 인해 CNCs 스스로가 열분해를 촉진시키는 산 촉매로 작용함으로써 이 구간의 열분해시작온도가 촉진된 것으로 보인다. CNCs 함량이 증가하면서 두 번째 구간의 CA 주 사슬의 열분해 촉진의 경우, CNCs가 열분해 되면서 많은 양의 분해가스를 생성하고, 이 가스들이 고분자 수지 내에 많은 빈 공간을 형성하고 고분자의 분해를 유도하는 방향으로 열확산 기작(mechanism)의 변화를 야기하기 때문으로 보인다(Leite et al., 2016). 결과적으로 황산 처리된 CNC 나노입자 첨가는 황산에 의해 표면에 형성된 sulfate기 때문에 고분자 복합소재의 열안정성을 향상시키지는 않는다. 그러나 CA와의 상용성이 높은 화학종으로 CNCs 표면을 화학적으로 개질하거나 난연제 도입으로 충분히 극복할 수 있을 것으로 판단된다. 


\section{4. 결 론}

본 연구는 선분산법과 압사출 방식을 이용한 CNCs의 첨가가 CA 나노복합재의 제조와 특성에 미치는 영향에 대해 분석하였 다. CA 복합소재 제조 시, 선분산법의 적용은 소재 내에서 $\mathrm{CNCs}$ 의 분산성 향상과 이로 인한 강화 효과 향상으로 복합재의 강도 성능을 향상시켰다. 하지만 $3 \mathrm{wt} . \%$ 초과 첨가 시에는 $\mathrm{CNCs}$ 의 퍼컬레이션 효과와 연관된 뭉침 현상을 일으켜 강도 값의 저하를 가져왔다. CNCs 첨가로 인해 CA 나노복합재의 열분해 온도는 약간 감소하여 열안정성을 향상시키지 않는 것으로 확인되었지만 CNCs의 표면 개질이나 난연성 재료의 투입 등으로 극복할 수 있는 정도인 것으로 판단된다. 따라서 선분산법을 이용해 CNCs를 첨가하고 압-사출 방식을 적용한 CA 나노복합재의 제조는 CA 복합소재의 단점으로 여겨지는 낮은 기계적 강도를 향상시키고 대량 생산을 가능케 하는 제조 방법으로 판단되어 많은 산업 분야에서 활용할 수 있을 것으로 판단된다. 